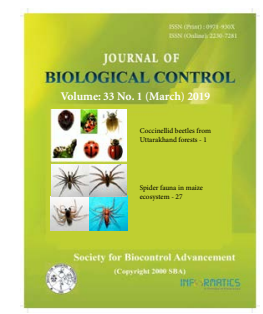

\title{
Variability in foraging behaviour, thermal requirement and virulence of entomopathogenic nematodes against sod webworm, Herpetogramma phaeopteralis Gueneè (Lepidoptera: Crambidae)
}

\author{
M. NAGESH*, M. BALACHANDER, T. M. SHIVALINGASWAMY, J. PATIL,A. N. SHYLESHA and A. RAGHAVENDRA \\ ICAR-National Bureau of Agricultural Insect Resources, P. B. No. 2491, H. A. Farm Post, Bellary Road, Hebbal, Bangalore \\ - 560024 , Karnataka, India. \\ *Corresponding Author E-mail: nagesh55@yahoo.com
}

\begin{abstract}
Variability in virulence among entomopathogenic nematodes, Heterorhabditis indica, H. bacteriophora and Steinernema abbasi, was studied for lethality, foraging behaviour in response to host volatiles, thermal requirements (degree-days), recyclability, persistence and field efficacy against Turfgrass Sod Webworm (TSW), Herpetogramma phaeopteralis. Comparatively, lethal concentration and time were lowest for $H$. indica against TSW. Recyclability of EPN ranged from $3.42 \times 10^{5}$ to $4.23 \times 10^{5} \mathrm{IJS}_{\mathrm{g}} \mathrm{g}^{1}$ of TSW. H. bacteriophora recorded highest movement rate on agar $(0.38-0.78 \mathrm{~cm})$ and sand-agar $(0.45-0.56 \mathrm{~cm})$, followed by $S$. abbasi, and $H$. indica. Responding to TSW volatiles, S. abbasi recorded maximum movement, H. bacteriophora, moderate, and H. indica, lowest. Heterorhabditis indica (with nictitation); S. abbasi and H. bacteriophora (without nictitation) were ambusher and cruiser, respectively. S. abbasi preferred warmer temperatures $\left(30-33^{\circ} \mathrm{C}\right)$, H. bacteriophora, moderate $\left(24-27^{\circ} \mathrm{C}\right)$, and $H$. indica, a wider range $\left(24-30^{\circ} \mathrm{C}\right)$, for virulence based on thermal requirement. In field, EPNs were comparable to chlorpyriphos against TSW. We demonstrated the complementarity of thermal preferences of EPNs and insect pest was critical besides attributes like foraging behaviour, recyclability, persistence, and lethality values for their success in the field.
\end{abstract}

Keywords: Degree-days, foraging, Herpetogramma phaeopteralis, Heterorhabditis indica, H. bacteriophora, sod webworm, Steinernema abbasi, thermal requirement, turfgrass, virulence, variability.

(Article chronicle: Received: 16-12-2018; Revised: 21-03-2019; Accepted: 25-03-2019)

\section{INTRODUCTION}

Turfgrass (sod) production is an important industry covering more than 25 million ha annually in tropical and subtropical regions (Haydu et al., 2006). Besides its recreational uses, turfgrass controls soil erosion, promotes and restores soil biological and physico-chemical properties, captures run-off water, and improves the aesthetics of urban landscapes. The production and maintenance are seriously affected by insect pests and diseases (Belair et al., 2010). Meagher et al., (2007) reported that wide outbreaks of Tropical Sod Webworm (TSW), Herpetogramma phaeopteralis Gueneè (Lepidoptera: Pyralidae) have significant economic importance on turfgrasses in over 100 countries in tropical and subtropical areas of the world. Sod webworm larvae feed on a variety of turfgrasses viz. Bermudagrass, Cynodon dactylon (L.), Persoon, centipede grass, Eremochloao phiuroides (Munro) Hackel, seashore paspalum, Paspalum vaginatum Swartz, St. Augustine grass, Stenotaphrum secundatum (Walter) Kuntze), and zoysia-grass, Zoysia japonica (Steude), especially on newly established sod, lawns, athletic fields, and golf courses, resulting in yellowing, drying and patchy growth of foliage (Reinert et al., 2009). Insecticides including Chlorpyrifos, phorate, carbaryl, pyrethroids, neonicoinoids, etc., are routinely and repeatedly administered for its control (Racke, 2000), and as a result, domestic animals and humans come in direct contact with these chemicals. Among the safer and effective alternatives to chemicals, biological control offers a potentially viable means of control on a long-term basis.

Use of Entomopathogenic nematodes (EPN) (Nematoda: Heterorhabditidae and Steinernematidae) could be a successful approach especially in the biological control of persistent insects in cryptic habitats (Lacey and Georgis, 2012) especially in lawn, turfgrass and landscape (Kaya, 1990; Grewal et al., 2005; Klein et al., 2007). Entomopathogenic nematodes are natural enemies of soil insect pests, and naturally harbor monoxenic bacterial symbionts. Together they cause insect mortality in 24 to $72 \mathrm{~h}$ depending on inset host, foraging strategies, exposure time and IJs concentration, soil type, etc., Tofangsazi et al., (2014) demonstrated that 
TBW could be controlled by using EPN formulations, with variability in virulence among species of EPN.

Considering the nature of occurrence of sod webworm in the top $5-7 \mathrm{~cm}$ of turfgrass roots, we hypothesized that the successful suppression of sod webworm in turfgrass largely depends on the foraging ability, recyclability and persistence of EPNs in turfgrass rhizosphere. Sod grasses absorb heat and keep the surface temperatures lower than the uncovered. The heat absorbed by the lawn/turf has a direct effect on the biology and multiplication of the pest, i.e., sod webworm, and the behaviour of EPNs. With this in mind, we examined the thermal requirements of the sod webworm life-stages and infectivity of three species of EPNs with different foraging behaviour, viz. Heterorhabditis indica, H. bacteriophora and Steinernema abbasi, under laboratory and field conditions. Entomopathogenic nematodes are expected to move actively in soil, primarily for insect hosts and or for favourable moisture and temperature zones. Therefore, in this study we examined the movement and behavioural responses of Infective Juveniles (IJ) of these nematodes to insect and moisture stimuli in the lab and tried to relate their relative efficacy against the target pest. Further, the studies included recyclability (in $H$. phaeopteralis larvae) and persistence or recovery of EPNs in treated turfgrass in order to observe their long-term benefit in sod webworm control.

\section{MATERIALS AND METHODS}

\section{Nematodes}

Three species of EPNs from a culture collection maintained by the National Bureau of Agricultural Insect Resources (NBAIR), Bengaluru, viz. Steinernema abbasi NBAIISa01 (NCBI Acc. No. HQ406728); Heterorhabditis indica NBAIIHi01 (NCBI Acc. No. HQ406730) and H. bacteriophora NBAIIHb05 (NCBI Acc. No. JN572120) were used for our laboratory and field studies. They were reared individually on late-instar larvae of the greater wax moth, Galleria mellonella L. (Lepidoptera: Pyralidae), at $28 \pm$ $2^{\circ} \mathrm{C}$ (Woodring and Kaya, 1988). Freshly emerged nematode juveniles, designated as IJ, were harvested (White, 1927), collected into tissue culture flasks, and used for experiments. Stocks were maintained in aqueous form at $10 \pm 2{ }^{\circ} \mathrm{C}$.

\section{Collection and maintenance of tropical sod webworm (TSW), Herpetogramma phaeopteralis}

The larvae of $H$. phaeopteralis were collected from infested turfgrass at NBAIR experimental fields, Yelahanka, Bengaluru (12 $\left.58^{\prime} 34^{\prime \prime} \mathrm{N}, 77^{\circ} 36^{\prime} 11^{\prime \prime} \mathrm{E} ; 914 \mathrm{~m}\right)$ by the method described by Niemczyk (1981). The soil was predominantly red laterite with $\mathrm{pH} 6.47$, organic carbon 0.88 and water holding capacity of 12-14\%. Five litres of water was sprinkled over an area of $1 \mathrm{~m}^{2}$ of $H$. phaeopteralis infested turfgrass.
Larvae that emerged to the surface were hand-picked and transferred to plastic trays $(40 \mathrm{~cm} \times 32 \mathrm{~cm} \times 8 \mathrm{~cm})$ containing pre-grown lawn of turfgrass. These trays were covered with black colour muslin cloth and maintained in a greenhouse at $28 \pm 2{ }^{\circ} \mathrm{C}$. Approximately equal sized larvae of average body length $15-16 \mathrm{~mm}$ with an average head capsule width of $1.374 \mathrm{~mm}\left(5^{\text {th }}\right.$ instar $)$ were used for bioassays.

\section{Behaviour and foraging of entomopathogenic nematodes (EPN)}

Behaviour and foraging features of freshly harvested IJs of EPNs were investigated on agar media, with and without sand, as per the method detailed by Noosidum et al. (2010), and Glazer and Lewis (2000). A separate set of plates with respective media were prepared with a provision for TSW body volatiles to record the movement of IJs in response to insect host stimuli as per Glazer and Lewis (2000). The number of IJs that moved to different quadrants and circles of the media in Petri plates were counted, and the net movement rate for the three nematode species were calculated as:

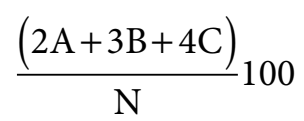

where A, B, C are the numbers of IJs in $2^{\text {nd }}, 3^{\text {rd }}$ and $4^{\text {th }}$ circles from centre of the Petri plate, respectively; 2, 3 and 4 are the distances in $\mathrm{cm}$ from the centre, and $\mathrm{N}$ is the total number of IJs in the opposite quadrants (Glazer and Lewis, 2000). Five replications were provided for each treatment.

In the case of host-stimuli-related movement assays of IJs (attraction assays), the protocols developed by Glazer and Lewis (2000) and Noosidum et al. (2010) were followed. The number of IJs in each arc in the quadrant containing the pipette tip with insect larva and the one opposite were counted every $5 \mathrm{~min}$ after introduction for $20 \mathrm{~min}$. Movement was calculated as:

$\frac{[(2 \mathrm{~A}+3 \mathrm{~B}+4 \mathrm{C})-(2 \mathrm{D}+3 \mathrm{E}+4 \mathrm{~F})]}{N} 100$

where A, B, C are the numbers of IJs in $2^{\text {nd }}, 3^{\text {rd }}$ and $4^{\text {th }}$ arcs from the centre with the pipette tip, respectively; D, E and $\mathrm{F}$ are the number of IJs in the $2^{\text {nd }}, 3^{\text {rd }}$ and $4^{\text {th }}$ arcs from the centre in the opposite quadrant, respectively; each number was multiplied by the distance in centimeters from the centre for each arc, and $\mathrm{N}$ was the total number of IJs in the opposite quadrants (Glazer and Lewis, 2000). Five replications were provided for each treatment.

Nematode juveniles were also examined directly and on agar media in Petri plates, under a stereo zoom 
microscope (light and phase contrast at $10-40 \times$ ), to record the visual observations on nematode behaviour and foraging. Accordingly, the three nematode species were classified in to different foraging groups (Glazer and Lewis, 2000).

Another set of plain Petri plates was maintained with four cadavers per plate at $28 \pm 2^{\circ} \mathrm{C}$ and near-saturated humidity. Cadavers were placed closely at the centre and a small wet cotton plug placed at the edge of the Petri plate. The cotton plug was maintained in wet to provide a moisture stimulus and observe the behaviour of IJs of three nematode species. Observations on aggregation, movement and body behaviour of IJs were observed visually under stereo zoom microscope.

\section{In vitro assays for virulence of EPN against TSW}

Nematode virulence was tested against $5^{\text {th }}$ instar larvae of $H$. phaeopteralis. Larvae were exposed to 25, 50, 100, 200 and $400 \mathrm{IJs}$ per Petri plate $(90 \times 12 \mathrm{~mm})$ lined with filter paper. Petri plates were provided with small bits of turfgrass as food for TSW larvae. The plates were incubated at $28 \pm 2^{\circ} \mathrm{C}$ in the dark. Five replicates of 25 larvae per treatment (five larvae per treatment) were maintained separately. Larvae treated with sterile distilled water served as control. Larval mortality was recorded at $12 \mathrm{~h}$ interval for 3 days, and dead larvae were dissected to determine the presence of nematodes.

Another set of 5-6 $6^{\text {th }}$ instar larvae were used for determining the lethal time of exposure required to achieve 50 and 90 per cent mortality at 100 IJs per Petri plate. The methodology essentially remained the same as above, and the exposure time was extended until the death of larvae.

\section{Influence of temperature on virulence of EPN (mortality period) against TSW}

Influence of temperature on the mortality period of field-collected TSW larvae was studied under green house conditions. About 3000 IJs of H. indica, S. abbasi and $H$. bacteriophora were prepared from fresh batches and inoculated in to the poly trays $(15 \mathrm{~cm} \mathrm{~h} \times 15 \mathrm{~cm} \mathrm{w} \times 15 \mathrm{~cm} \mathrm{l})$ containing pre-grown turf grass. Ten $5^{\text {th }}$ and $6^{\text {th }}$ instar larvae were released per pot and kept at constant temperatures of 18 , $23,27,30$ and $33^{\circ} \mathrm{C}$, respectively. Observations were recorded on mortality days to understand the influence of temperature on the virulence of EPNs against TSW larvae.

\section{Influence of temperature on survival and development of TSW}

The effect of temperature on the developmental stages period of TSW (laboratory reared and field collected strains) was studied under laboratory conditions. Ten TSW females from the laboratory-reared and field (collected in batches from light traps in the vicinity of affected turfs and lawns) each were kept at different temperatures of 18, 23, 27, 30 and $33^{\circ} \mathrm{C}$ for egg laying, larval growth, pupation and adult emergence. Observations were recorded on larval and pupal periods, and adult emergence to understand the influence of temperature on development of the two strains of TSW.

\section{Recyclability of entomopathogenic nematodes on TSW}

Recyclability of EPNs on TSW was estimated in terms of progeny production of the three nematodes on $5^{\text {th }}$ instar sod webworm larvae. Larvae were individually exposed to each nematode species at a concentration of 100 IJs per Petri plate and incubated for $48-72 \mathrm{~h}$ at $28 \pm 1^{\circ} \mathrm{C}$. Subsequently, cadavers were individually placed in Petri plates lined with moist filter paper and incubated at $28 \pm 1{ }^{\circ} \mathrm{C}$ for $4-5$ days for the IJs to emerge from the cadavers. Emerged IJs were then collected into $150 \mathrm{ml}$ plastic cup every day until the emergence of IJs completely ceased and were designated as stock. Further, a set of $5^{\text {th }}$ instar $G$. mellonella larvae was also maintained as positive check for comparison. Progeny production of each nematode species on TSW and G. mellonella were determined by counting the IJs from stock through serial dilution under stereo zoom microscope $40 \times$.

\section{Field evaluation of entomopathogenic nematode strains against TSW}

Field studies were conducted at two locations in the TSW-infested lawns at the NBAIR experimental fields, Yelahanka Campus, Bengaluru, during November 2013 and March 2014 with different, but fresh batches of nematodes. Soil type was red laterite with $\mathrm{pH}$ 6.74, organic carbon 0.88 and water holding capacity of $12-14$ percent. Thirtysix microplots of $3 \times 3 \mathrm{~m}^{2}$ size each were demarcated with a plastic sheet barrier $(3 \mathrm{~m} \times 3 \mathrm{~m} \times 15 \mathrm{~cm})$ placed for each plot to a depth of $15 \mathrm{~cm}$. The treatments included aqueous suspensions of $H$. indica, $S$. abbasi and H. bacteriophoraeach at $6.0 \times 10^{6} \mathrm{IJs}$ per plot with Chlorpyrifos $2.5 \mathrm{ml}$ per litre water as chemical control and untreated control. The Latin Square Design model was used for conducting the experiments. The number of live larvae per $\mathrm{m}^{2}$ was sampled at 10,20 and 30 days after imposing the treatments in the same fashion as explained earlier (Niemczyk, 1981). Corrected mortality of larvae was calculated as per Abbot's formula and expressed in percentage. Mean values were arcsine transformed and subjected to analysis using LSD (least significant difference). Recommended agronomical practices were followed.

Persistence of nematodes in turf was determined at 10, 20 and 30 Days After Treatment (DAT). One hundred cc of soil samples $(5-7 \mathrm{~cm}$ depth) were drawn from EPNs-treated plots and used for insect-baiting technique. Ten $5^{\text {th }}$ instar larvae of G. mellonella were placed in containers with soil samples, incubated at $30 \pm 1{ }^{\circ} \mathrm{C}$ for $96 \mathrm{~h}$ and recorded larval 
mortality due to EPN infection. Each treatment was replicated three times. Mean values were converted to percent larval mortality, and the standard error was calculated.

\section{Data analysis}

Differences in life-stage parameters between laboratoryreared and field-collected strains of TSW and, virulence of EPN at different temperatures were compared using $t$-test. The day-degrees were calculated using a modified formula given by Dhillon and Sharma (2009). Total daydegrees for treatments under constant temperatures $=$ total development period (days) $\times$ temperature of exposure; while total degree-days for treatments under ambient conditions $=$ total development period (days) $\times$ average of minimum and maximum temperatures across the development period.

Experiments on bioassay and progeny production (recyclability) of EPN were repeated twice using different, but fresh nematode batches, and the data on larval mortality were pooled. Larval mortality was corrected according to Abbott (1925) prior to statistical analysis. The data on larval mortality in relation to dose and exposure time to entomopathogenic nematodes were log-transformed. The values were subjected to Probit analysis (Probit model of Pearson Goodness of Fit Test at $\alpha=0.05 \%$ significance level) to determine lethal concentration $\left(\mathrm{LC}_{50}\right.$ and $\left.\mathrm{LC}_{90}\right)$ and lethal time $\left(\mathrm{LT}_{50}\right.$ and $\left.\mathrm{LC}_{90}\right)$ using SPSS 16.0 for Windows.

\section{RESULTS AND DISCUSSION}

\section{Behaviour and foraging of infective juveniles of EPN}

In EPN movement rate studies, Heterorhabditis bacteriophora recorded the highest movement rate on agar and sand-agar in the range of $0.38-0.78 \mathrm{~cm}$ and $0.45-0.56 \mathrm{~cm}$, respectively, across the time, followed by Steinernema abbasi with $0.29-0.60 \mathrm{~cm}$ and $0.36-0.72 \mathrm{~cm}$, respectively (Table 1 ). $H$. indica recorded a movement rate of $0.10-0.35 \mathrm{~cm}$ on agar and $0.15-0.48 \mathrm{~cm}$ on sand-agar, in $45 \mathrm{~min}$. of observation. Although all three nematode species were attracted to TSW volatiles, foraging movement of $H$. indica was $0.18-0.46 \mathrm{~cm}$, while $H$. bacteriophora and $S$. abbasi recorded a movement of $0.42-0.85$ and $0.31-0.68 \mathrm{~cm}$, respectively (Table 1 ). Visual observations under a stereo zoom microscope on the behaviour of IJs on agar and sand-agar showed that $H$. indica exhibited wavy and s-shaped movement, while IJs of $S$. abbasi and H. bacteriophora exhibited deep s-shaped active and vigorous movement. Infective juveniles of $H$. indica recorded nictitation, i.e. tails of IJs were attached to the substrate (sand particles), with body in upright position freely in space and body moving actively in wavy fashion (Table 2). Infective juveniles of $H$. bacteriophora and $S$. abbasi did not record this behaviour and they remained

Table 1. Movement rate of infective juveniles of Heterorhabditis indica, $\boldsymbol{H}$. bacteriphora and Steinernema abbasi in the presence and absence of TSW volatiles

\begin{tabular}{|c|c|c|c|c|c|c|}
\hline \multirow{2}{*}{$\begin{array}{l}\text { Nema- } \\
\text { tode } \\
\text { Species }\end{array}$} & \multicolumn{3}{|c|}{ Average movement rates $(x \pm \mathrm{SE}) \mathrm{cm}$} & \multicolumn{3}{|c|}{$\begin{array}{l}\text { Average movement rates }(\times \pm \mathrm{SE}) \mathrm{cm} \text { in the } \\
\text { presence of TSW volatiles }\end{array}$} \\
\hline & $15 \mathrm{~min}$ & $30 \mathrm{~min}$ & $45 \mathrm{~min}$ & $15 \mathrm{~min}$ & $30 \mathrm{~min}$ & $45 \mathrm{~min}$ \\
\hline H. indica & \begin{tabular}{|l|}
$0.10 \pm$ \\
$0.02 \mathrm{a}(\mathrm{a}) * / * /$ \\
$0.15 \pm$ \\
$.03 \mathrm{a}(\mathrm{a}) * / * *$ \\
\end{tabular} & $\begin{array}{l}0.16 \pm \\
0.02 \mathrm{a}(\mathrm{a})^{* /} \\
0.18 \pm \\
0.02 \mathrm{a}(\mathrm{a}) * *\end{array}$ & \begin{tabular}{|l|}
$0.35 \pm$ \\
$0.02 \mathrm{a}(\mathrm{ab})^{* /}$ \\
$0.48 \pm$ \\
$0.03 \mathrm{a}(\mathrm{ab})^{* *}$ \\
\end{tabular} & $\begin{array}{l}0.18 \pm \\
0.02 \mathrm{a}(\mathrm{ab})\end{array}$ & $\begin{array}{l}0.22 \pm \\
0.03 \mathrm{a}(\mathrm{ab})\end{array}$ & $0.46 \pm 0.03 \mathrm{a}(\mathrm{bc})$ \\
\hline $\begin{array}{l}\text { H. } \\
\text { bacterio- } \\
\text { phora }\end{array}$ & \begin{tabular}{|l|}
$0.38 \pm 0.02 \mathrm{c}$ \\
$(\mathrm{bc})^{* /}$ \\
$0.45 \pm 0.04 \mathrm{c}$ \\
$(\mathrm{bc})^{* *}$ \\
\end{tabular} & $\begin{array}{l}0.62 \pm \\
0.02 \mathrm{c}(\mathrm{cd}) * / \\
0.48 \pm \\
0.07 \mathrm{bc}(\mathrm{bc})^{* *}\end{array}$ & \begin{tabular}{|l|}
$0.78 \pm$ \\
$0.0 \mathrm{c}(\mathrm{d}) 3^{* /}$ \\
$0.56 \pm$ \\
$0.03 \mathrm{bc}(\mathrm{cd}) * *$ \\
\end{tabular} & $\begin{array}{l}0.42 \pm \\
0.03 \mathrm{c}(\mathrm{bc})\end{array}$ & $\begin{array}{l}0.69 \pm \\
0.02 \mathrm{c}(\mathrm{cd})\end{array}$ & $0.85 \pm 0.04 \mathrm{c}(\mathrm{d})$ \\
\hline S. abbasi & $\begin{array}{l}0.29 \pm 0.04 b c \\
(b c)^{* /} \\
0.36 \pm 0.06 b c \\
(b c)^{* *}\end{array}$ & $\begin{array}{l}0.45 \pm \\
0.05 \mathrm{bc}(\mathrm{bc})^{* /} \\
0.52 \pm \\
0.06 \mathrm{bc}(\mathrm{cd})^{* *}\end{array}$ & $\begin{array}{l}0.60 \pm \\
0.01 \mathrm{c}(\mathrm{cd}) * / \\
0.72 \pm \\
0.08 \mathrm{c}(\mathrm{d}) * * \\
\end{array}$ & $\begin{array}{l}0.31 \pm \\
0.02 \mathrm{bc}(\mathrm{b})\end{array}$ & $\begin{array}{l}0.56 \pm \\
0.06 \mathrm{bc}(\mathrm{c})\end{array}$ & $\begin{array}{l}0.68 \pm \\
0.06 \mathrm{bc}(\mathrm{cd})\end{array}$ \\
\hline \multicolumn{4}{|c|}{$\begin{array}{l}\text { Means were arcsine transformed and subjected to two-way } \\
\text { ANOVA Means followed by the same letter are not significantly } \\
\text { different by LSD at } \alpha=0.05 \text { between isolates. Means followed } \\
\text { by same letter in parenthesis are not significantly different at } \\
\alpha=0.05 \text { between time. There was no significance difference } \\
\text { between * smooth agar plate; } * * \text { sandy agar plate at } \alpha=0.05\end{array}$} & & & \\
\hline
\end{tabular}


Variability in foraging behaviour, thermal requirement and virulence of entomopathogenic nematodes against sod webworm

in crawling position. Infective juveniles of $H$. indica that emerged from cadavers on dry Petri plates characteristically aggregated and moved in radiating threads towards moisture droplets whereas IJs of $H$. bacteriophora were observed to aggregate, moved in small numbers, rarely in threads, while $S$. abbasi juveniles aggregated, actively moved individually or in small numbers, and thread formation was absent. None of the IJs were observed to show jumping behaviour movement, perhaps requiring a special set of experimental conditions for observation.

The behaviour of IJs, i.e. non-feeding and free-living stage of EPN, were reported to be highly variable and correlated to their host searching ability and host infectivity (Campbell and Gaugler, 1993, 1997). EPN have been categorized as ambushers, cruisers and intermediate foragers based on a suite of behavioural features (Lewis, 2002). Noosidum et al., (2010) reported that all Heterorhabditis spp., characterized from Thailand, did not exhibit body-waving and standing behaviours, while the Steinernema isolates were more of intermediate foragers. Standing and jumping behaviour of IJs was attributed to cruiser forager (Campbell and Gaugler, 1993; 1997). In this study, we observed that IJs of $H$. indica not only moved relatively slower on agar and sand-agar than the IJs of H. bacteriophora and S. abbasi, but also exhibited nictitation and s-shaped movement; while the IJs of $H$. bacteriophora and $S$. abbasi did not show nictitation but exhibited active movement in deep s-shaped fashion. These observations suggest that $H$. indica was an ambusher than a cruiser, while $H$. bacteriophora and $S$. abbasi were cruiser type foragers as observed by Lewis and co-workers (Lewis et al., 1992; Lewis, 2002).
Attraction to host volatile cues was prominent in cruiser type foragers and not prominent in ambusher (Lewis et al., 1993). We observed that attraction of H. bacteriophora and $S$. abbasi to TSW volatile cues was significantly higher than that of $H$. indica, thus supporting the observations that these are cruiser type foragers. We also observed that besides host volatile cues, the nematodes characteristically were attracted and tactile to moisture. Infective juveniles of Heterorhabditis indica emerging from a Galleria cadaver on a dry Petri plate (with water droplets/moist cotton placed at a distance in the Petri plate) in response to moisture stimulus, first aggregated in to radiating threads or strands and then moved towards moisture, adhering to one another. This behaviour of aggregation and movement in strands was as well observed in H. bacteriophora but to a lesser extent, while IJs of S. abbasi preferred to actively move individually or in smaller number.

Infective juveniles are known to actively move in soil mainly in search of food, or for avoiding adverse abiotic stress. The common stimuli for their movement include host cues, moisture, temperature and $\mathrm{pH}$. As observed in our study, relatively slow movement in simple s-shape manner and nictitation (standing and body-wave motion), in case of $H$. indica, were characteristic to an ambusher, while active and deep s-shape movement of IJs with no nictitation were characteristic to cruising type of foraging nematodes. Similar observations by Campbell and Gaugler $(1993,1997)$ and Lewis et al. (1993), supporting that $H$. indica strain under study can be categorized as an ambusher and $H$. bacteriophora and $S$. abbasi as cruisers. We believe that the behaviour of aggregation and movement in strands in response to moisture stimulus, as in case of $H$. indica, can be mistaken for cruising type of foraging.

Table 2. Behaviour of infective juveniles of Heterorhabditis indica, H. bacteriphora and Steinernema abbasi in the presence and absence of TSW volatiles and moisture

\begin{tabular}{|l|l|l|l|}
\hline \multirow{2}{*}{ Nematode species } & \multicolumn{3}{|c|}{ Visual observations under microscope (40-60×) } \\
\cline { 2 - 4 } & \multicolumn{1}{|c|}{ IJs on agar medium } & IJs on sandy agar medium & \multicolumn{1}{|c|}{$\begin{array}{c}\text { IJs in dry conditions in a } \\
\text { Petri plate }\end{array}$} \\
\hline H. indica & $\begin{array}{l}\text { S-shaped movement, jump- } \\
\text { ing not prominently ob- } \\
\text { served. }\end{array}$ & $\begin{array}{l}\text { IJs nictitate on sand parti- } \\
\text { cles, jumping not promi- } \\
\text { nently observed. }\end{array}$ & $\begin{array}{l}\text { IJs aggregate, move in radiat- } \\
\text { ing threads towards moisture } \\
\text { droplets. }\end{array}$ \\
\hline S. abbast & $\begin{array}{l}\text { Deep s-shaped, active and } \\
\text { vigorous movement, no } \\
\text { jumping. }\end{array}$ & No nictitation, no jumping. & $\begin{array}{l}\text { IJs aggregate, move in small } \\
\text { numbers, rarely in threads. }\end{array}$ \\
\hline $\begin{array}{l}\text { Deep s-shaped, active and } \\
\text { vigorous movement, no } \\
\text { jumping }\end{array}$ & No nictitation, no jumping. & $\begin{array}{l}\text { IJs aggregate, actively move } \\
\text { individually or in small } \\
\text { numbers, thread formation is } \\
\text { absent. }\end{array}$ \\
\hline
\end{tabular}




\section{In vitro assays for virulence of EPN against TSW}

Heterorhabditis indica recorded the lowest $\mathrm{LC}_{50}$ and $\mathrm{LC}_{90}$ values (30 and $131 \mathrm{IJ}$, respectively), followed by $S$. abbasi and H. bacteriophora, which recorded 97 and 515, and 111 and 1252 IJs, respectively (Table 3). As the lowest slope value indicates the highest virulence, a lowest slope value of 1.5 was observed for $H$. indica. Similar trend was observed for $G$. mellonella, a positive check, with lowest LC values for $H$. indica, followed by $H$. bacteriophora and $S$. abbasi. In comparison, the LC values for $G$. mellonella were about 2.5 to 3.0 times lower than that of the LC values recorded for $H$. phaeopteralis for all the three nematodes. Herpetogramma phaeopteralis required higher inocula of EPN compared with G. mellonella to accomplish median and 90\% larval mortality
$\left(\mathrm{LC}_{50}\right.$ and $\left.\mathrm{LC}_{90}\right)$. These observations indicated two types of variability related to virulence of EPNs viz., variability among EPN species and variability due to insect host. Earlier Tofangsazi et al., (2014) studied the effect of commercial formulations of five EPN species against TSW and reported variability in virulence among five EPN species against TSW.

Influence of temperature on virulence of EPN against TSW

The effect of temperature on virulence of EPN against $5^{\text {th }}$ and $6^{\text {th }}$ instar larvae of TSW (in terms of exposure period required for larval mortality) was studied under controlled conditions. Exposure period required for larval mortality at $18,23,27,30$ and $33^{\circ} \mathrm{C}$ were different for different nematode species (Fig. 1, 2; Table 7). At $18^{\circ} \mathrm{C}$, the number of days

Table 3. Lethal concentration of Steinernema abbasi, Heterorhabditis indica and H. bacteriphora (IJs per larva) required to cause pathogenicity on the 5 th instar larvae of Herpetogramma phaeopteralis

\begin{tabular}{|l|c|c|c|c|c|c|c|c|c|}
\hline $\begin{array}{c}\text { Nematode } \\
\text { species }\end{array}$ & Slope $\pm \mathrm{SE}$ & LC $_{50} \mathrm{IJ}$ & $95 \%$ C.L. & $\begin{array}{c}\mathrm{LC}_{90} \\
\mathrm{IJS}_{\mathrm{S}}\end{array}$ & $95 \%$ C.L. & $\chi^{2}$ & $d f$ & $P$ & $\begin{array}{c}\text { Progeny } \\
\text { production of } \\
\text { IJs per g body } \\
\text { weight of larva }\end{array}$ \\
\hline S. abbasi & $3.53 \pm 0.63$ & 97 & $69-36$ & 515 & $309-1349$ & 2.154 & 3 & 0.541 & $3.92 \times 10^{3}$ \\
\hline H.indica & $1.53 \pm 0.57$ & 30 & $16-42$ & 131 & $90-266$ & 4.585 & 3 & 0.205 & $4.22 \times 10^{3}$ \\
\hline $\begin{array}{l}\text { H. } \\
\text { bacterio- } \\
\text { phora }\end{array}$ & $2.42 \pm 0.76$ & 111 & $69-186$ & 1252 & $523-11546$ & 0.310 & 3 & 0.958 & $3.44 \times 10^{3}$ \\
\hline
\end{tabular}

In time-mortality response at $100 \mathrm{IJs}, H$. indica was observed to be the most virulent against $H$. phaeopteralis with significantly lower $\mathrm{LT}_{50}$ and $\mathrm{LC}_{90}$ values ( 21 and $72 \mathrm{~h}$, respectively) followed by $S$. abbasi (52 and 101, respectively) and H. bacteriophora (73 and 127, respectively) (Table 5). In case of G. mellonella, positive check, $\mathrm{LT}_{50}$ and 90 were significantly lower for all the three nematode species (Table 6) compared to H. phaeopteralis, and similar to the trend as observed with LC values. G. mellonella required shorted exposure time to nematodes in order achieve desired mortality compared to that of $H$. phaeopteralis.

Table 4. Lethal concentration of Steinernema abbasi, Heterorhabditis indica and $\boldsymbol{H}$. bacteriphora (IJs per larva) required to cause pathogenicity on the 5th instar larvae of Galleria mellonella

\begin{tabular}{|l|c|c|c|c|c|c|c|c|c|}
\hline $\begin{array}{c}\text { Nematode } \\
\text { species }\end{array}$ & Slope $\pm \mathrm{SE}$ & LC $_{50}$ IJs & $95 \%$ C.L. & $\begin{array}{c}\text { LC }_{90} \\
\mathrm{IJs}\end{array}$ & $95 \%$ C.L. & $\chi^{2}$ & $d f$ & $P$ & $\begin{array}{c}\text { Progeny } \\
\text { production of } \\
\text { IJs per g body } \\
\text { weight of larva }\end{array}$ \\
\hline S. abbasi & $3.04 \pm 0.61$ & 28 & $16-44$ & 172 & $119-386$ & 1.154 & 3 & 0.414 & $5.48 \times 10^{5}$ \\
\hline H.indica & $1.13 \pm 0.54$ & 12 & $7-28$ & 88 & $68-212$ & 3.413 & 3 & 0.338 & $6.72 \times 10^{5}$ \\
\hline $\begin{array}{l}\text { H. } \\
\text { bacterio- } \\
\text { phora }\end{array}$ & $2.12 \pm 0.76$ & 24 & $14-40$ & 149 & $102-346$ & 2.312 & 3 & 0.578 & $5.13 \times 10^{5}$ \\
\hline
\end{tabular}


Table 5. Exposure time of Steinernema abbasi, Heterorhabditis indica and $H$. bacteriphora required to cause mortality to the 5th instar larvae of Herpetogramma phaeopteralis

\begin{tabular}{|l|c|c|c|c|c|c|c|c|}
\hline $\begin{array}{c}\text { Nematode } \\
\text { species }\end{array}$ & Slope $\pm \mathrm{SE}$ & LT $_{50}$ Hrs. & 95\% C.L. & LT $_{90}$ Hrs. & $95 \%$ C.L. & $\chi^{2}$ & $d f$ & $P$ \\
\hline S. abbasi & $7.55 \pm 1.36$ & 52 & $45-60$ & 101 & $81-157$ & 5.239 & 4 & 0.264 \\
\hline H.indica & $3.30 \pm 0.69$ & 21 & $15-27$ & 72 & $54-122$ & 4.891 & 4 & 0.299 \\
\hline H. bacteriophora & $9.88 \pm 2.32$ & 73 & $63-99$ & 127 & $95-285$ & 4.699 & 4 & 0.320 \\
\hline
\end{tabular}

Table 6. Exposure time of Steinernema abbasi, Heterorhabditis indica and $\boldsymbol{H}$. bacteriphora required to cause mortality to the 5th instar larvae of Galleria mellonella

\begin{tabular}{|l|c|c|c|c|c|c|c|c|}
\hline \multicolumn{1}{|c|}{ Nematodes } & Slope $\pm \mathrm{SE}$ & LT $_{50}$ Hrs. & 95\% C.L. & LT $_{90}$ Hrs. & 95\% C.L. & $\chi^{2}$ & $d f$ & $P$ \\
\hline S. abbasi & $3.55 \pm 1.12$ & 41 & $30-56$ & 54 & $41-72$ & 4.139 & 4 & 0.410 \\
\hline H.indica & $2.10 \pm 0.29$ & 17 & $12-26$ & 36 & $28-48$ & 3.112 & 4 & 0.599 \\
\hline H. bacteriophora & $2.88 \pm 1.22$ & 33 & $28-43$ & 49 & $35-67$ & 3.729 & 4 & 0.452 \\
\hline
\end{tabular}

Table 7. Mortality of TSW larvae exposed to Heterorhabditis indica, H. bacteriphora and Steinernema abbasi at different temperatures

\begin{tabular}{|c|c|c|c|c|c|}
\hline \multirow{2}{*}{$\begin{array}{c}\text { Temperature } \\
\left({ }^{\circ} \mathrm{C}\right)\end{array}$} & \multicolumn{3}{|c|}{$\begin{array}{c}\text { Number of days required for TSW larval mortality exposed to } \\
\text { different EPN species (mean } \pm \text { SE) }\end{array}$} & & \multirow[t]{2}{*}{$t$ - Value $d f=7$} \\
\hline & H. indica & H. bacteriophora & S. abbasi & & \\
\hline & \multicolumn{5}{|c|}{ Exposure period for 5th instar larval mortality (days) } \\
\hline 18 & $3.6 \pm 0.22 b(b c)$ & $4.5 \pm 0.24 \mathrm{c}(\mathrm{cd})$ & $5.9 \pm 0.11 \mathrm{c}(\mathrm{cd})$ & \multicolumn{2}{|c|}{1.99} \\
\hline 23 & $2.3 \pm 0.34 \mathrm{ab}(\mathrm{ab})$ & $3.6 \pm 0.26 b(b c)$ & $4.6 \pm 0.12 \mathrm{c}(\mathrm{cd})$ & \multicolumn{2}{|c|}{1.81} \\
\hline 27 & $1.8 \pm 0.13 a(a)$ & $2.3 \pm 0.32 \mathrm{a}(\mathrm{ab})$ & $3.8 \pm 0.22 b(b c)$ & \multicolumn{2}{|c|}{0.21} \\
\hline 30 & $2.4 \pm 0.12 \mathrm{ab}(\mathrm{ab})$ & $2.8 \pm 0.11 \mathrm{a}(\mathrm{ab})$ & $2.2 \pm 0.23 \mathrm{a}(\mathrm{ab})$ & \multicolumn{2}{|c|}{0.39} \\
\hline 33 & $3.3 \pm 0.10 \mathrm{~b}(\mathrm{bc})$ & $3.8 \pm 0.10 b(b c)$ & $3.3 \pm 0.21 b(b c)$ & \multicolumn{2}{|c|}{1.26} \\
\hline & \multicolumn{5}{|c|}{ Exposure period for 6th instar larval mortality (days) } \\
\hline 18 & $5.2 \pm 0.30 \mathrm{~cd}(\mathrm{~d})$ & $5.8 \pm 0.12 \mathrm{~d}(\mathrm{~d})$ & \multicolumn{2}{|c|}{$5.9 \pm 0.14 \mathrm{~d}(\mathrm{~d})$} & 1.96 \\
\hline 23 & $3.5 \pm 0.21 b c(b c)$ & $4.9 \pm 0.26 \mathrm{~cd}(\mathrm{~d})$ & \multicolumn{2}{|c|}{$5.0 \pm 0.12 \mathrm{~cd}(\mathrm{~d})$} & 1.63 \\
\hline 27 & $2.6 \pm 0.36 \mathrm{a}(\mathrm{a})$ & $3.1 \pm 0.11 \mathrm{ab}(\mathrm{bc})$ & \multicolumn{2}{|c|}{$3.3 \pm 0.23 \mathrm{bc}(\mathrm{bc})$} & 0.42 \\
\hline 30 & $2.8 \pm 0.12 \mathrm{ab}(\mathrm{a})$ & $3.3 \pm 0.12 b c(b c)$ & \multicolumn{2}{|c|}{$2.9 \pm 0.22 \mathrm{ab}(\mathrm{a})$} & 0.31 \\
\hline 33 & $4.2 \pm 0.22 \mathrm{c}(\mathrm{cd})$ & $4.8 \pm 0.71 \mathrm{c}(\mathrm{cd})$ & \multicolumn{2}{|c|}{$3.8 \pm 0.16 \mathrm{bc}(\mathrm{c})$} & 1.82 \\
\hline
\end{tabular}

Note: Means were arcsine transformed and subjected to two-way ANOVA. Means followed by the same letter are not significantly different by LSD at $\alpha=0.05$ between temperature; Means followed by same letter in parenthesis are not significantly different at $\alpha=0.05$ between isolates

required for $5^{\text {th }}$ instar larval mortality were $3.6 \pm 0.22,4.5$ \pm 0.24 and $5.9 \pm 0.11$ days, respectively for $H$. indica, $H$. bacteriophora and $S$. abbasi, and for $6^{\text {th }}$ instar larval mortality, the number of days required were $5.2 \pm 0.30,5.8 \pm 0.12$ and
$5.9 \pm 0.10$ days. At $33^{\circ} \mathrm{C}$, exposure period required for $5^{\text {th }}$ instar larval mortality were $3.3 \pm 0.10,3.8 \pm 0.10$ and $3.3 \pm$ 0.21 days, respectively, for $H$. indica, H. bacteriophora and S. abbasi and $4.2 \pm 0.22,4.8 \pm 0.70$ and $3.8 \pm 0.10$ days, 
Table 8. Survival and development of laboratory and field strains of TSW at different temperatures

\begin{tabular}{|c|c|c|c|}
\hline $\begin{array}{l}\text { Life table parameters/ temperature } \\
\qquad\left({ }^{\circ} \mathrm{C}\right)\end{array}$ & $\begin{array}{l}\text { Laboratory strain (Mean } \\
\quad \pm \mathrm{SE} \text { ) }\end{array}$ & Field strain $($ Mean $\pm \mathrm{SE})$ & $t$ - Value $d f=7$ \\
\hline & \multicolumn{2}{|c|}{ Larval period (days) } & \\
\hline 18 & $50.8 \pm 2.19 \mathrm{c}$ & $53.5 \pm 2.21 \mathrm{c}$ & $-2.87 * *$ \\
\hline 23 & $48.6 \pm 4.32 b c$ & $49.4 \pm 3.10 b c$ & -1.54 \\
\hline 27 & $36.9 \pm 1.16 \mathrm{a}$ & $39.3 \pm 2.12 \mathrm{a}$ & $-0.32 *$ \\
\hline 30 & $35.4 \pm 2.22 \mathrm{a}$ & $35.1 \pm 1.38 \mathrm{a}$ & $-0.97 *$ \\
\hline \multirow[t]{2}{*}{33} & $47.6 \pm 3.17 \mathrm{bc}$ & $50.8 \pm 1.11 \mathrm{c}$ & -2.45 \\
\hline & \multicolumn{2}{|c|}{ Pupal period (days) } & \\
\hline 18 & $7.4 \pm 0.29 b c$ & $8.1 \pm 0.20 \mathrm{~d}$ & $-1.57 * *$ \\
\hline 23 & $7.0 \pm 0.15 b c$ & $7.8 \pm 0.22 \mathrm{~cd}$ & -0.98 \\
\hline 27 & $5.6 \pm 0.22 \mathrm{a}$ & $6.3 \pm 0.23 \mathrm{ab}$ & $-0.21 *$ \\
\hline 30 & $5.9 \pm 0.10 \mathrm{a}$ & $6.9 \pm 0.15 \mathrm{ab}$ & $-0.47 *$ \\
\hline \multirow[t]{2}{*}{33} & $6.8 \pm 0.30 \mathrm{ab}$ & $7.3 \pm 0.18 b c$ & -1.44 \\
\hline & \multicolumn{2}{|c|}{ Adult emergence (\%) } & \\
\hline 18 & $42.6 \pm 0.93 \mathrm{~d}$ & $38.6 \pm 0.21 \mathrm{~d}$ & $-4.57 * *$ \\
\hline 23 & $54.2 \pm 0.67 \mathrm{c}$ & $46.5 \pm 0.18 \mathrm{~cd}$ & -3.98 \\
\hline 27 & $92.8 \pm 0.39 a$ & $90.6 \pm 0.53 a$ & $-1.21 *$ \\
\hline 30 & $86.4 \pm 0.49 \mathrm{ab}$ & $93.2 \pm 0.61 \mathrm{a}$ & $-1.47 *$ \\
\hline 33 & $67.6 \pm 0.84 b c$ & $74.5 \pm 0.82 b$ & -3.44 \\
\hline
\end{tabular}

Note: *,* Values are significant at $P \leq 0.05$ and 0.01 , respectively; the means were angular transformed and subjected to $t$-test using SPSS 16.0.

respectively, for $6^{\text {th }}$ instar larval mortality. Significantly, temperatures that favoured minimum number of days for $5^{\text {th }}$ and $6^{\text {th }}$ instar larval mortality, for $H$. indica $(1.80 \pm 0.22$ days, $2.60 \pm 0.36$ days), H. bacteriophora (2.30 \pm 0.32 days, $3.10 \pm$ 0.11 days) and $S$. abbasi $(2.20 \pm 0.23$ days, $2.90 \pm 0.22$ days respectively) were 27,27 and $30^{\circ} \mathrm{C}$, respectively. Significantly, at $27^{\circ} \mathrm{C} \mathrm{H}$. indica and $H$. bacteriophora recorded the lowest number of days for $5^{\text {th }}$ and $6^{\text {th }}$ instar larval mortality at $27^{\circ} \mathrm{C}$, i.e. $1.8 \pm 0.13$ and $2.6 \pm 0.36$, and $2.3 \pm 0.32$ and $3.1 \pm 0.11$ days, respectively, and at $30^{\circ} \mathrm{C} \mathrm{S}$. abbasi recorded the lowest number of days for $5^{\text {th }}$ and $6^{\text {th }}$ instar larval mortality $(2.2 \pm$ 0.23 and $2.9 \pm 0.22$ days, respectively) at $30^{\circ} \mathrm{C}$, indicating variability in thermal preferences by the EPN for virulence.

The relationship between temperature and virulence of each nematode species against TSW larvae was further elaborated based on the degree-days at different temperatures. Number of degree-days for larval mortality were lowest for H. indica (94, 60 and 44 degree-days, respectively) at 18, 23 and $27^{\circ} \mathrm{C}$ compared with $H$. bacteriophora (118, 94 and 60 degree-days, respectively) and $S$. abbasi (153, 120 and 95degree-days, respectively). At higher temperatures of 30 and $33^{\circ} \mathrm{C}$, the number of degree-days was lowest for S. abbasi (57 and 87 degree-days, respectively), followed by $H$. indica (61 and 87 degree-days, respectively) and $H$. bacteriophora (74 and 97 degree-days, respectively) for $5^{\text {th }}$ instar larval mortality. For $6^{\text {th }}$ instar larval mortality at $30^{\circ} \mathrm{C}$, H. indica and S. abbasi were statistically on par (72 and 77 degree-days, respectively); and at $33^{\circ} \mathrm{C}, S$. abbasi recorded lowest degree-days of 97 followed by $H$. indica (110 degreedays) and $H$. bacteriophora (123 degree-days).

\section{Influence of temperature on development of soil stages (larva and pupa) of TSW}

Data on effect of specific temperatures $(18,23,27,30$ and $33^{\circ} \mathrm{C}$ ) on developmental periods of TSW life-stages and adult emergence are given in Table 8. Larval periods for laboratory-reared and field strains of TSW ranged between 35.4 and 50.8, and 35.1 and 53.5 degree-days, respectively, and pupal periods between 5.6 and 7.4 degree-days and 6.3 and 8.1 degree-days, respectively, at different temperatures. Larval and pupal periods were longer at lower temperature of 
$18^{\circ} \mathrm{C}$ for both the laboratory-reared and field strains of TSW. With increase in temperature from 18 to $30^{\circ} \mathrm{C}$, the number of days required for larval period decreased to 35.5 and 35.1 degree-days, respectively. At $33^{\circ} \mathrm{C}$ the larval period for laboratory-reared and field strain recorded an increase (47.6 and 50.8 degree-days). Pupal period too recorded an increase in number of degree-days at $33^{\circ} \mathrm{C}$.

The association between temperature and longevity of TSW developmental stages were examined based on degree-days at different temperatures. Laboratory-reared TSW recorded a minimum of 917 degree-days at $30^{\circ} \mathrm{C}$, and a maximum of 1310 degree-days at $18^{\circ} \mathrm{C}$ for complete development, while the field strain recorded a minimum of 876 and a maximum of 1325 degree-days at 30 and $18^{\circ} \mathrm{C}$, respectively (Figure 3 ).

Thermal requirement of life-stages of TSW and virulence of EPN were examined in terms of degreedays to understand their mutual behaviour in different temperature regimes and identify mutually favourable temperature regimes. Between 18 and $27^{\circ} \mathrm{C}$, the number of degree-days for TSW larval mortality was the lowest for $H$. indica compared with $H$. bacteriophora and $S$. abbasi. At higher temperatures $\left(30\right.$ and $\left.33^{\circ} \mathrm{C}\right)$ the number of degreedays was the lowest for $S$. abbasi, followed by $H$. indica and H. bacteriophora for TSW larval mortality. Number of degree-days for TSW larval stages was lowest at $27-30^{\circ} \mathrm{C}$, indicating that the ideal overlapping temperatures for the insect pest (TSW) and virulence of the three nematodes. More specifically, $S$. abbasi preferred warmer temperatures of $30-33^{\circ} \mathrm{C}$, while $\mathrm{H}$. bacteriophora, milder temperatures of $24-27^{\circ} \mathrm{C}$, and $H$. indica, a wider range of temperatures, $24-30^{\circ} \mathrm{C}$, for virulence. Based on these observations we hypothesize that the thermal requirements of EPNs and a target insect pest contribute significantly to the success of EPN, thus and a specific nematode species can be employed for specific temperature regime in field.

Hill et al. (2015) reported acute thermal limits for survival and the thermal acclimation-related plasticity thereof for two key endemic South African EPN species, $S$. yirgalemense and $H$. zealandica. Shapiro et al. (2014) demonstrated that the $H$. floridensis strains possessed a wide niche breadth in temperature tolerance and had virulence and desiccation levels that were similar to a number of other EPNs. The strains may be useful for biocontrol purposes in environments where temperature extremes occur within short durations. These studies actually refer to the tolerance limits of the nematodes under controlled conditions, while our study demonstrated the actual thermal requirements of the EPNs for virulence and the relevance of matching thermal requirements of EPNs with that of pests.

\section{Recyclability (progeny production) of EPN on TSW larvae}

Progeny production of $H$. indica, $H$. bacteriophora and S. abbasi in the larvae of H. phaeopteralis and G. mellonella (a positive control) were estimated and expressed in terms of yield per gram of larval body weight for comparison. Progeny production of these nematode species on $H$. phaeopteralis ranged between $3.44 \times 10^{3}$ and $4.22 \times 10^{3}$ per g body weight, with a maximum yield of IJs of $H$. indica $\left(4.22 \times 10^{3}\right)$ followed by $S$. abbasi $\left(3.92 \times 10^{3} \mathrm{IJs}\right)$ and H. bacteriophora $(3.44 \times$ $10^{3} \mathrm{IJs}$ ) (Table 10). Progeny production of the senematodes in G. mellonella was 1.2 to 1.6 times higher than that in $H$. phaeopteralis. Estimation of recyclability/productivity of EPN helps in possible survivability and persistence of these nematodes in treated fields/rhizosphere.

\section{Field evaluation of EPN against TSW}

Data recorded in two field trials, on the effect of EPNs on TSW populations at 10, 20 and 30 DAT, are presented in Table 9. In Trial-1, 10 DAT, S. abbasi, H. bacteriophora and $H$. indica recorded 22, 40 and 57\% reduction in larval populations of TSW, respectively and Chlorpyrifos-treated plots recorded a reduction of $31 \%$. At 20 and 30 DAT, $S$. abbasi recorded 31 and $47 \%$ reduction in TSW larval populations; H. bacteriophora, 52 and $68 \%$, and H. indica, 69 and $83 \%$ reduction, respectively, while there was 48 and $37 \%$ reduction in Chlorpyrifos-treated plots. In Trial-2, similar trends were observed on the effect of EPN on TSW larval populations at all the three time intervals (Table 9). Compared to Trial-1, larval population reduction was significantly higher in $S$. abbasi treated plots, whereas, reduction in larval populations was at parin $H$. indica and $H$. bacteriophora treated plots in Trial-2. Among the three EPN species, $H$. indica recorded maximum reduction in TSW populations in both the trials. In Ttrial-1, H. bacteriophora recorded higher reduction of TSW populations compared to $S$. abbasi, while $S$. abbasi performed better than H. bacteriophora in Trial-2. Chlorpyrifos recorded comparatively lower reduction in TSW populations in Trial-2 than in Trial-1. In both the trials EPN treatments were superior to Chlorpyrifos treatment in reducing TSW populations.

All the three nematode species were recovered from respective treated plots at 15,30 and $60 \mathrm{DAT}$ at two different trial sites (Table 10) indicating their persistence in turfgrass for 60 days. Kurtz et al. (2007) investigated the establishment and the short- and long-term persistence of H. bacteriophora, H. megidis and S. feltiae in three maize fields in southern Hungary, using the insect-baiting technique. All three EPN species equally established and persisted in maize fields. EPNs persisted for 2-5 months, i.e. they survived up to and throughout the crop period. 
Table 9. Effect of EPN treatments on population density of Herpetogramma phaeopteralis in two trials

\begin{tabular}{|c|c|c|c|c|c|c|c|}
\hline \multirow{3}{*}{ Treatments } & \multirow{3}{*}{$\begin{array}{c}\text { Initial } \\
\text { population } \\
\text { per } \mathrm{m}^{2}\end{array}$} & \multicolumn{3}{|c|}{ TRIAL -1 } & \multicolumn{3}{|c|}{ TRIAL -2 } \\
\hline & & \multicolumn{3}{|c|}{$\begin{array}{l}\text { Reduction in population density per } \\
\mathrm{m}^{2}(\%)\end{array}$} & \multicolumn{3}{|c|}{$\begin{array}{l}\text { Reduction in population density per } \\
\mathrm{m}^{2}(\%)\end{array}$} \\
\hline & & $10 \mathrm{DAT}$ & 20 DAT & 30 DAT & $10 \mathrm{DAT}$ & 20 DAT & 30 DAT \\
\hline S. abbasi & $91 \pm 0.2$ & $22 \pm 0.2 \mathrm{~d}$ & $31 \pm 1.4 \mathrm{~d}$ & $47 \pm 1.7 \mathrm{c}$ & $47 \pm 0.8 \mathrm{c}$ & $60 \pm 1.4 b$ & $74 \pm 1.6 \mathrm{ab}$ \\
\hline indica & $95 \pm 1.3$ & $57 \pm 0.6 b c$ & $69 \pm 1.2 b$ & $83 \pm 0.6 a$ & $58 \pm 0.9 \mathrm{bc}$ & $61 \pm 1.0 \mathrm{~b}$ & $86 \pm 0.3 \mathrm{a}$ \\
\hline H. bacteriophora & $98 \pm 2.6$ & $40 \pm 0.5 \mathrm{~cd}$ & $52 \pm 0.9 b c$ & $65 \pm 0.9 b$ & $32 \pm 1.3 \mathrm{~d}$ & $57 \pm 1.5 b c$ & $61 \pm 0.8 b$ \\
\hline Chlor-pyrifos & $86 \pm 2.4$ & $31 \pm 0.4 \mathrm{~d}$ & $48 \pm 0.8 \mathrm{c}$ & $37 \pm 1.7 \mathrm{~d}$ & $27 \pm 1.2 \mathrm{~d}$ & $30 \pm 0.3 \mathrm{~cd}$ & $19 \pm 1.4 \mathrm{~d}$ \\
\hline Untreated control* & $93 \pm 1.7$ & $110 \pm 0.8$ & $116 \pm 0.6$ & $121 \pm 0.4$ & $101 \pm 1.8$ & $98 \pm 1.9$ & $119 \pm 1.4$ \\
\hline
\end{tabular}

Note:*Untreated control values signify increase in population density recorded in untreated control over different DAT, while other values signify the percentage reduction in population density in all other treated plots over respective untreated controls. DAT denotes Days After Treatment. Means followed by the same letter are not significantly different by LSD at $\alpha=0.05$ between days.

Table 10. Recovery of Steinernema abbasi, Heterorhabditis indica and $H$. bactriophora from the treated turf grass micro plots and recyclability of these nematode species on TSW

\begin{tabular}{|l|c|c|c|c|c|c|c|c|}
\hline \multirow{2}{*}{ Nematode species } & \multicolumn{6}{|c|}{ Recovery of EPNs on Galleria mellonella } & $\begin{array}{c}\text { Progeny production of } \\
\text { IJs per g body weight } \\
\text { of larva }\end{array}$ \\
\cline { 2 - 9 } & \multicolumn{3}{|c|}{ TRIAL -1 } & \multicolumn{3}{c|}{ TRIAL - } & TSW & $\begin{array}{c}\text { G. mel- } \\
\text { lonella }\end{array}$ \\
\cline { 2 - 9 } & 15 DAT & 30 DAT & 60 DAT & 15 DAT & 30 DAT & 60 DAT & & \\
\hline S. abbasi & $62 \pm 0.3 \mathrm{bc}$ & $48 \pm 1.2 \mathrm{~b}$ & $22 \pm 1.0 \mathrm{bc}$ & $66 \pm 1.2 \mathrm{a}$ & $32 \pm 1.4 \mathrm{~b}$ & $20 \pm 1.4 \mathrm{~b}$ & $3.92 \times 10^{5}$ & $5.48 \times 10^{5}$ \\
\hline H. indica & $86 \pm 2.6 \mathrm{a}$ & $89 \pm 1.0 \mathrm{a}$ & $85 \pm 1.2 \mathrm{a}$ & $61 \pm 0.9 \mathrm{a}$ & $82 \pm 2.0 \mathrm{a}$ & $70 \pm 0.8 \mathrm{a}$ & $4.22 \times 10^{5}$ & $6.72 \times 10^{5}$ \\
\hline H. bacteriophora & $50 \pm 1.9 \mathrm{c}$ & $45 \pm 0.8 \mathrm{~b}$ & $32 \pm 0.3 \mathrm{~b}$ & $59 \pm 1.3 \mathrm{ba}$ & $27 \pm 1.7 \mathrm{cb}$ & $18 \pm 0.8 \mathrm{cb}$ & $3.44 \times 10^{5}$ & $5.13 \times 10^{5}$ \\
\hline
\end{tabular}

Note: Means followed by the same letter are not significantly different by LSD at $\alpha=0.05$ between days.

Previously, Tofangsazi et al., (2014) demonstrated that $S$. carpocapsae caused the highest mortality in comparison to S. feltiae, $H$. bacteriophora, $H$. megidis and $H$. indica against TSW, using their commercial formulations. Studies have also established the efficacy and applicability of EPNs against other insect pests of turfgrass. Steinernema carpocapsae was the best performing species than S. feltiae and H. bacteriophora, against black cutworm, Agrotisipsilon, on golf turf, indicating that there was inter-generic variation in efficacy (Ebssa and Koppenhofer, 2011). Similarly, Koppenhofer et al., (2006) observed inter-generic variation in virulence among $H$. bacteriophora, H.indica, H. zealandicaand S. scarabaei against five white grub species (Coleoptera: Scarabaeidae) of economic importance in turfgrass.

\section{CONCLUSION}

Efficacy of all the three nematode species was comparable to that of Chlorpyrifos against TSW, as they possessed additional attributes like foraging and recyclability. Among the three EPNs studied, Heterorhabditis indica recorded lowest LC and LT values, better recyclability, field efficacy and persistence. We demonstrated that in addition to LC values, attributes like foraging behaviour, recyclability (progeny production in insect host) and persistence in treated locations, complementarity of thermal preferences of the target insect pest and the EPNs is critical feature for the success of EPNs in field on long-term basis. These attributes also help us in deciding the field dose, method and time of application of EPNs matching to the variability in EPNs and the insect pest.

\section{ACKNOWLEDGEMENTS}

The authors are thankful to Dr. Abraham Verghese, Director, National Bureau of Agricultural Insect Resources (NBAIR), Bengaluru, for providing necessary facilities to carry out the work. 


\section{REFERENCES}

Abbott WS. 1925. A method of computing the effectiveness of an insecticide. J Econ Entomol. 18: 265-267. https:// doi.org/10.1093/jee/18.2.265a.

Bélair G, Koppenhöfer AM, Dionne J, Simard L. 2010. Current and potential use of pathogens in the management of turfgrass insects as affected by new pesticide regulations in North America. Intl J Pest Manage. 56: 51-60. https:// doi.org/10.1080/09670870903076012.

Campbell JF, Gaugler R. 1993. Nictation behavior and its ecologicalimplications in the host search strategies of entomopathogenic nematodes (Heterorhabditidae and Steinernematidae). Behaviour 126: 155-169. https:// doi.org/10.1163/156853993X00092.

Campbell JF, Gaugler R. 1997. Inter-specific variation in entomopathogenicnematode foraging strategy: dichotomy or variation along a continuum. Fundam Appl Nematol. 20: 393-398.

Dhillon MK, Sharma HC. 2009. Temperature influences the performance and effectiveness of field and laboratory strains of the ichneumonid parasitoid, Campoletis chlorideae. BioControl 54: 743-750. https://doi.org/10.1007/s10526-009-9225-x.

Ebssa L, Koppenhofer AM. 2011. Efficacy and persistence of entomopathogenic nematodes for black cutworm control in turfgrass. Biocontrol SciTechn. 21: 779-796. https://doi.org/10.1080/09583157.2011.584610.

Glazer I, Lewis EE. 2000. Bioassays for entomopathogenic nematodes. pp. 229-247. In: Navon A, Ascher KRS (Eds.). Bioassays of Entomopathogenic Microbes and Nematodes. Wallingford, UK: CABI Publishing. https://doi.org/10.1079/9780851994222.0229.

GrewalPS, KoppenhoferAM, ChooHY.2005.Lawn, turfgrass, and pasture applications. Pp.115-146. In: Grewal PS, Ehlers RU, and Shapiro-Ilan DI, (Eds.). Nematodes as biocontrol agents. Wallingford: CABI Publishing. https://doi.org/10.1079/9780851990170.0115.

Haydu JJ, Hodges AW, Hall CR. 2006. Economic impacts of the turfgrass and lawncare industry in the United States. University of Florida, IFAS, EDIS document FE 632.

Hill MP, Malan AP, Terblanche JS. 2015. Divergent thermal specialisation of two South African entomopathogenic nematodes. Peer J. 3: e1023. http://doi.org/10.7717/ peerj.1023. https://doi.org/10.7717/peerj.1023.
Kaya HK. 1990. Soil ecology. Pp. 93-115. In: Gaugler R and Kaya HK, (Eds.). Entomopathogenic nematodes in biological control. Boca Raton: CRC Press.

Klein MG, Grewal PS, Jackson TA, Koppenhofer AM. 2007. Lawn, turf and grassland pests.Pp. 655-675. In: Lacey LA and Kaya HK (Eds.), Field Manual of Techniques in Invertebrate Pathology: Application and evaluation of pathogens for control of insects and other invertebrate pests. Second Edition. Dordrecht: Springer. https://doi. org/10.1007/978-1-4020-5933-9_32.

Koppenhofer AM, Grewal PS, Fuzy EM. 2006. Virulence of the entomopathogenic nematodes, Heterorhabditis bacteriophora, Heterorhabditis zealandica, and Steinernema scarabaei against five white grub species (Coleoptera: Scarabaeidae) of economic importance in turfgrass in North America. Biol Control 38: 397-404. https://doi.org/10.1016/j.biocontrol.2005.12.013.

Kurtz B, Toepfer S, Ehlers RU, Kuhlmann U. 2007, Assessment of establishment and persistence of entomopathogenic nematodes for biological control of western corn rootworm. J Appl Entomol. 131: 420-425. doi: $10.1111 / \mathrm{j} .1439-0418.2007 .01202$. https://doi. org/10.1111/j.1439-0418.2007.01202.x.

Lacey AL, Georgis R. 2012. Entomopathogenic nematodes for control of insect pests above and below ground with comments on commercial production. J Nematol. 44(2): $218-225$

Lewis EE. 2002. Behavioral Ecology. Pp. 205-224. In: Gaugler R, (Ed.), Entomopathogenic Nematology. Wallingford: CABI Publishing. https://doi. org/10.1079/9780851995670.0205.

Lewis EE, Gaugler R, Harrison R. 1992. Entomopathogenic nematodehost finding: response to host contact cues by cruise and ambush foragers. Parasitology 105: 309-315. https://doi.org/10.1017/S0031182000074230.

Lewis EE.Gaugler R, Harrison R. 1993. Response of cruiser and ambusher entomopathogenic nematodes (Steinernematidae) in host volatile cues. Can J Zool. 71: 765-769. https://doi.org/10.1139/z93-101.

Meagher RL, Epsky ND, Cherry R. 2007. Mating behavior and female-produced pheromones use in tropical sod webworm (Lepidoptera: Crambidae). Fla Entomol. 90: 304-308. https://doi.org/10.1653/ 0015-4040(2007)90[304:MBAFPU]2.0.CO;2. 
Niemczyk HD. 1981. Destructive turf insects. HDN Book Sales. Wooster, OH. 48 pp.

Noosidum A, Hodson AK, Lewis EE, Chandrapatya A. 2010. Characterization of new entomopathogenic nematodes from Thailand: foraging behavior and virulence to the Greater wax moth, Galleria mellonella L. (Lepidoptera: Pyralidae). J Nematol. 42: 281-291.

Racke KD. 2000. Pesticide for turfgrass pest management uses and environmental issues. Pp-45. In: Clark M and M. P. Kennum MP (Eds.), Fate and Management of turf grass chemicals. https://doi.org/10.1021/bk-2000-0743. ch003.

Reinert JA, Engelke MC, Genovesi AD, Chandra A, McCoy JE. 2009. Resistance to tropicalsod webworm (Herpetogramma phaeopteralis) (Lepidoptera:Crambidae) in St. Augustine grass and zoysia grass. Intl Turfgrass Society Res J. 11: 663-673.

Shapiro-Ilan DI, Blackburn D, Duncan L, El-Borai FE, Koppenho"fer H, Tailliez P, Adams BJ. 2014.
Characterization of biocontrol traits in Heterorhabditis floridensis: A species with broad temperature tolerance. J Nematol. 46(4): 336-345.

Tofangsazi N, Cherry RH, Arthurs SP. 2014. Efficacy of commercial formulations of entomopathogenic nematodes against tropical sod webworm, Herpetogramma phaeopteralis (Lepidoptera: Crambidae). J Appl Entomol. DOI: 10.1111/jen.12125. https://doi.org/10.1111/jen.12125.

White GF. 1927. A method for obtaining infective nematode from cultures. Science 66: 302- 303. https://doi. org/10.1126/science.66.1709.302-a.

Woodring LJ and Kaya KH. 1988. Steinernematid and Heterorhabditid nematodes. A handbook of biology and techniques. Southern Cooperative Series Bulletin. A publication ofthe nematode subcommittee of the Southern Research Project S135- Entomopathogens foruse in Pest Management Systems. 